There is some evidence for the antitumor effect of heparins, especially the lowmolecular-weight ones. The authors discuss the potential mechanism of this antineoplastic effect and present results from several in vitro and in vivo experiments. The clinical trials concerning the impact of low-molecularweight heparins on the tumor and on the patients' survival are described. The objective was to find out if heparins could be administered as an antitumor drug, independently of their anticoagulatory properties.

The antitumor role of tissue factor, heparinase, chemokines, stromal proteins, cellular interactions as well as angiogenesis and immunology seems certain. The results of the available studies seem promising but large clinical trials are necessary in order to confirm the antineoplastic effect of the low-molecular-weight heparins and to approve them for standard anticancer treatment. It could be a breakthrough in modern oncology.

Key words: heparins, cancer, tissue factor, chemokines, cellular interactions, venous thromboembolism.

\section{The antineoplastic effect of low-molecular-weight heparins - a literature review}

\author{
Justyna Bochenek, Mirosława Püsküllüoğlu, Krzysztof Krzemieniecki
}

Department of Clinical Oncology, Krakow University Hospital, Krakow, Poland

\section{Heparins - what are they?}

Unfractionated heparin (UFH) and its derivatives, low-molecular-weight heparins $(\mathrm{LMWH})$, are anticoagulants, from the glycosaminoglycans group [1]. LMWH, first introduced into treatment in the mid 1980s, have lower molecular weight than UFH, from which they are obtained by chemical or enzymatic depolymerization. LMWH differ from each other by their pharmacokinetic and anticoagulatory properties. Their mean molecular weight is 4500-5000 Daltons (Da), with a range from 1000 to $10000 \mathrm{Da}$ [2]. In comparison to UFH, LMWH do not inhibit thrombin, as they do not possess the specific pentasaccharide sequence essential for interaction with antithrombin III. They neutralize coagulation factor Xa [3].

Heparins induce tissue factor pathway inhibitor (TFPI) secretion by the vascular endothelium, which also determines their anticoagulatory effect. They may bind platelets, inhibiting or stimulating their aggregation, according to the trial's conditions [4]. Heparins also affect vascular permeability [5], inhibit endothelial smooth muscle proliferation [6] and osteoblast formation, and activate osteoclast production [7]. These effects are independent from anticoagulation. They are shown in Fig. 1.

Complications associated with heparins include hemorrhage, osteoporosis and hyperkalemia. Two types of thrombocytopenia after heparin administration have been described - immunological (heparin-induced thrombocytopenia) and non-immunological. Elderly patients with a history of malignancy, receiving additional treatment, are particularly exposed to these complications [2].

\section{Association of venous thromboembolism with cancer}

All three elements of Virchow's triad - hypercoagulability, hemodynamic changes and endothelial dysfunction - contribute to venous thromboembolism (VTE) in the state of malignancy. Cancer cells produce coagulation and fibrinolysis modifiers such as tissue factor (TF), cancer procoagulant, human leukocyte antigen DR, the platelet aggregation/coagulation agent platelet and coagulation factor $X$ activator, mucous glycoprotein, coagulation factor $V$ and its receptor [8]. Tumor cells are also a source of cytokines stimulating the release of procoagulant factors by macrophages and endothelial cells. All these mechanisms lead to the activation of coagulation factor $X$ and the clotting cascade. In a study of patients with idiopathic thrombosis, almost 10\% were diagnosed with cancer in 5-10 subsequent years [9].

Cancer as a single negative prognostic factor increases the VTE risk over 4 times, while chemotherapy leads to a 6.5-fold change [10]. Hemostasis disorder is the second most frequent cause of death among cancer patients and coagulation hyperactivity is confirmed among $90 \%$ of them [11]. Patients with aggressive, metastatic disease are at the highest risk. Adenocarcinoma of the prostate and colon cancer among males and lung and ovarian tumors among females are related to a particularly high risk of VTE [12]. Moreover, surgery, chemotherapy and 


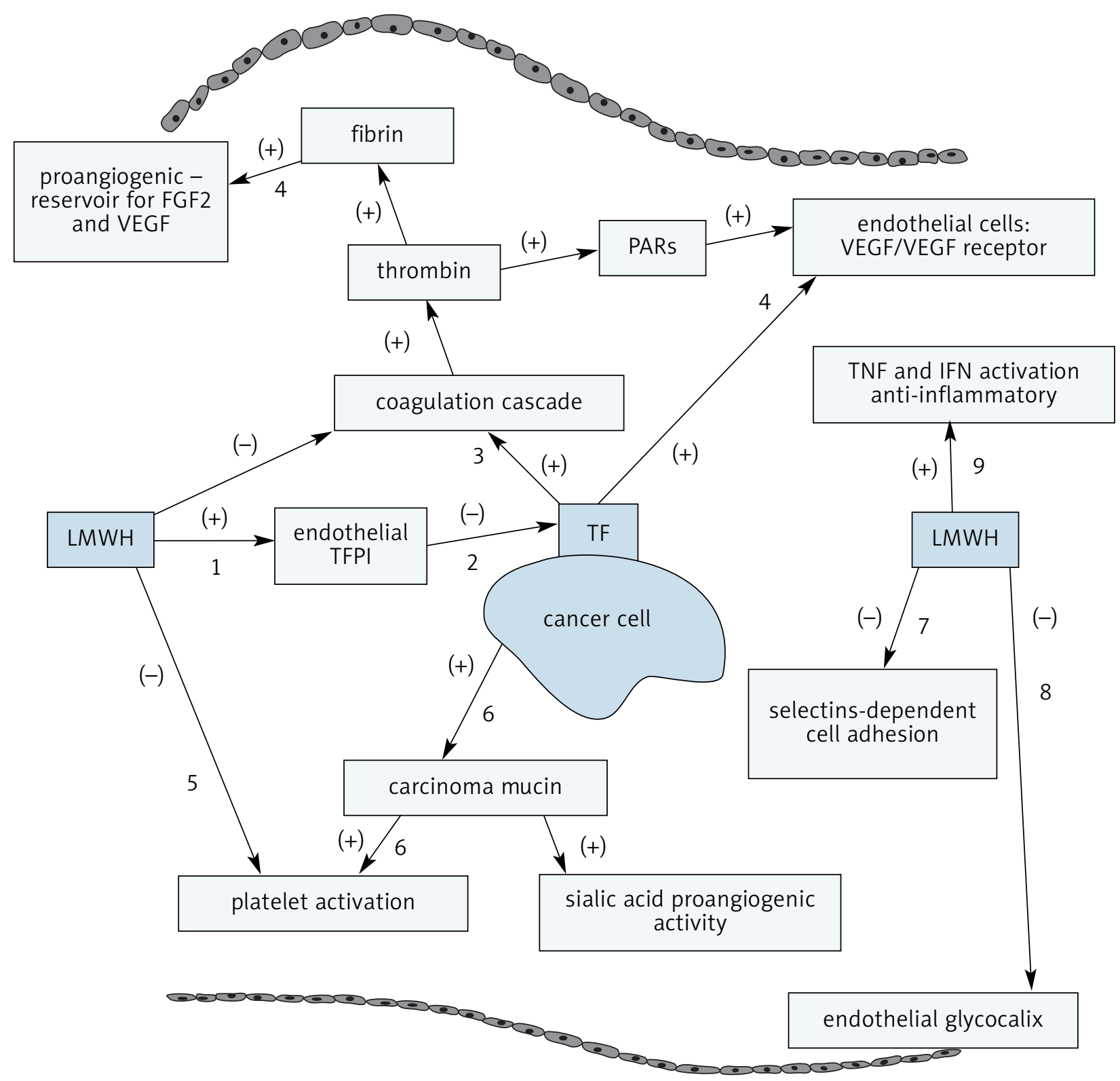

LMWH stimulate secretion of the endothelial TFPI (1) which inhibits TF (2) expressed on the surface of the cancer cell. TF activates the coagulation cascade (3) as well as stimulating growth factor and cytokine production (4). LMWH inhibit (5) cancer cell-dependent (6) platelet activation. Additionally, LMWH influence stromal proteins by inhibition of selectin-dependent cell adhesion (7) and endothelial glycocalyx (8). Finally, LMWH act in an anti-inflammatory capacity (9).

Fig. 1. Potential mechanisms of the anticancer action of the low-molecular-weight heparins

antiangiogenic treatment increase this risk. Finally, malignancy may be accompanied by VTE of untypical location [13].

Many patients with cancer are elderly, with prior surgical history and decreased mobility. This coincidence of negative prognostic factors makes estimating the VTE risk hard. We lack prospective studies on this topic. The risk factors are summarized in Table 1.

\section{Heparin administration among patients with cancer}

LMWH are administered in low doses in the primary prophylaxis and in high doses in venous thromboembolism (VTE) treatment.
The principles of prophylaxis and treatment with LMWH among patients with cancer are described by international societies of clinical oncology, such as ASCO (the American Society of Clinical Oncology), ESMO (the European Society for Medical Oncology) and the National Comprehensive Cancer Network (NCCN). ASCO recommendations give the answers to five questions: Should patients with cancer receive VTE prevention: 1) during hospitalization; 2) during ambulatory chemotherapy; 3) around surgery? There are also guidelines concerning: 4) patients with established VTE and 5) LMWH use to improve survival [14].

ESMO guidelines published in 2009 are generally similar to ASCO's [15]. There are differences concerning patients 
Table 1. Risk factors for venous thromboembolism among cancer patients [14]

$\begin{array}{lll}\text { Patient-related factors } & \text { Cancer-related factors } & \text { Treatment-related factors } \\ \text { age } & \text { primary site of cancer: } & \text { recent major surgery } \\ \text { race } & \text { - digestive system } & \text { current hospitalization } \\ \text { comorbid conditions (obesity, infection etc.) } & - \text { brain } & \text { active chemotherapy } \\ \text { prior history of venous thromboembolism } & - \text { lung } & \text { active hormonal therapy } \\ \text { elevated prechemotherapy platelet count } & - \text { reproductive system } & \text { current or recent antiangiogenic therapy } \\ \text { heritable prothrombic mutations } & - \text { kidney } & \text { current erythropoiesis-stimulating agents } \\ & - \text { hematopoietic system } & \text { presence of central venous catheters } \\ & \text { initial 3-6 months after cancer diagnosis } & \end{array}$

receiving hormonal therapy, adjuvant chemotherapy and with an implanted venous catheter, who do not require prophylaxis according to ESMO. NCCN recommends prophylactic anticoagulation therapy in all inpatient cases of cancer if not contraindicated and in ambulatory cancer surgery patients as well as in medical oncology patients at risk [16].

Generally, most recommendations are in accordance with the lack of need to use LMWH for increasing survival among patients with malignancy. At the same time, all recommendations suggest conducting large clinical trials on the positive effect of LMWH on cancer patients' survival.

\section{Mechanisms of anti-cancer action}

Metastasis is a multistep process. Cancer cells have to enter the circulatory system, evade being recognized by the immune cells there, adhere to the endothelium of the targeted organ and colonize its tissues. Neoangiogenesis is required to sustain the tumor formation [17]. A number of possible mechanisms of antineoplastic effect of LMWH have been suggested. There is evidence for heparins' inhibitory action on each of the above-mentioned steps as well as on tumor growth. The role of tissue factor, heparinase, chemokines, stromal proteins, cellular interactions as well as angiogenesis and immunology will be mentioned.

\section{Tissue factor - is it the key factor?}

TF forms a macromolecular complex with factor VII to activate both factor XI and X. The TF-factor VIla complex directly stimulates production of growth factors, such as the vascular endothelial growth factor (VEGF), and cytokines [18]. It may also prolong cancer cells' survival by p44/42 MAPK and Jak/STAT signaling $[19,20]$. LMWH stimulate secretion of TFPI from the vascular endothelium. TFPI inhibits the signal for tumor growth and neoangiogenesis transferred by the TF [21-23]. Heparin's ability to stimulate TFPI depends on the weight of its molecule [24]. Heparin chains of 6000-8000 Da are the most effective, among them tinzaparin with $6500 \mathrm{Da}[25]$.

\section{Chemokines}

The formation of metastases may be reduced because of chemokine receptor 4 (CXCR4) signaling inhibition by LMWH. The overexpression of CXCR4 has been confirmed in metastasizing cancer cells of many different types. In the target organs - lungs, liver, lymph nodes, brain and bones - overexpression or abnormal activity of the ligand for CXCR4, stromal cell-derived factor-1 (SDF-1), was found [26]. CXCR4 contributes to the cancer cells' epithelial-mesenchymal transformation.

According to a study on Chinese hamsters, LMWH (tinzaparin) inhibits CXCR4-SDF1 interaction by binding SDF1. In that study, heparin reduced the frequency of metastases of breast cancer [27].

\section{Stromal proteins}

Another possible mechanism of anti-tumor action is the influence on the endothelial glycocalyx. The damage of the glycocalyx by enzymes such as heparinase and hyaluronidase increases the vascular permeability. Glycocalyx modulates the cell adhesion to the endothelium by P- and L-selectins and syndecan-1, which also has an impact on the fibroblast growth factor 2 (FGF-2) and VEGF activity [28, 29]. Moreover, glycocalyx is a reservoir of anti-apoptotic growth factors and a source of pro-angiogenic proteins and cytokines that facilitate tissue permeability. Therefore, it has pro-metastatic properties. Heparin may also compete with the proteoglycan chains of heparin sulfate, which regulate metastasis formation [30].

\section{Trans-cellular and cellular-matrix contacts}

The anti-metastatic effect of LMWH may depend on the inhibition of endothelial cell adhesion. VLA4/VCAM-1 interaction and selectin binding seem to be targets [31]. Selectin$P$ is expressed on activated platelets, selectin-E on activated endothelial cells, while selectin-L is constitutively present on leukocytes [32, 33]. Selectins may recognize the sialyl structures, mainly of the mucin type that are expressed on almost all cancer cells. A positive correlation between sialyl-Lewis $x$ and poor prognosis in stomach, colon, lung, prostate and breast cancer was observed [32]. Interactions between selectins, cancer cells, platelets, leukocytes and endothelial cells were studied in mice with different degrees of selectin expression. L-selectin deficiency was associated with metastasis reduction. However, the same effect was observed among mice with knock-out genes for both P- and L-selectins [34], so the two types of selectins may act synergistically. Heparin may inhibit both P- and L-selectins [35] as well as binding of sLe $x$ [36]. A single heparin dose reduces metastases in the wild type to the level of the P-selectin knock-out gene population [37-39]. In the P- and L-selectin deficient mouse, heparin did not inhibit metastases [34], but repeated doses prolonged survival, suggesting that selectin inhi- 
bition is only one of the mechanisms of antineoplastic action of LMWH [40]. Tinzaparin was confirmed to inhibit selectins most effectively among the LMWH [41].

\section{Angiogenesis}

Heparin leads to the stabilization of proangiogenic growth factors stored in the extracellular matrix, of which the most important are VEGF and FGF-2. In an experimental model of human colon cancer, tinzaparin administration 24 hours after angiogenesis stimulation by VEGF led to a decrease of the angiogenic index to the control level [42]. The anti-angiogenic effect of LMWH was also studied in vitro on human umbilical vein endothelial cells. LMWH inhibited tubule formation, in a dose-dependent manner [43].

In the literature available, one example of a proangiogenic effect of LMWH in vivo was found. In this study angiogenesis to the rat mesentery assays was induced by intraperitoneal injection of very low doses of VEGF. Dalteparin and epirubicin were administered separately or in combination by subcutaneous infusion for 14 consecutive days. Dalteparin significantly stimulated angiogenesis in an inversely dosedependent manner, epirubicin did not significantly affect it, and concurrent treatment with dalteparin and epirubicin significantly inhibited angiogenesis, which suggest a complex drug effect [44].

\section{Immunology}

Another explanation of these anti-cancer properties may be immunomodulation. LMWH enhance the activity of natural killers. Heparins act through tumor necrosis factor and interferon activity stimulation [45]. They may also inhibit the activation of leukocytes, complement system and complement-dependent inflammation. Heparins contribute to neutrophil extravasation and they interfere with free oxygen radical production in neutrophils [46].

\section{Heparinase - potential target}

Another possible mechanism of the antineoplastic effect of LMWH is the inhibition of heparinase, which may facilitate stromal invasion by cancer cells. Heparins inhibit heparinase mRNA and activity in metastatic lung cancer in vivo in rats [47]. The elevated serum and urinary level of heparinase was confirmed among patients with aggressive cancer at advanced stages [48]. The heparinase activity correlates with the metastatic potential of melanoma B16 and Epstein lymphoma in animal models $[49,50]$.

Heparinase may also, independently of its enzymatic properties, facilitate Akt-dependent endothelial cell invasion and migration, and may upregulate VEGF gene expression through Src activation [51].

\section{Other possible mechanisms}

LMWH stop cell proliferation by inhibition of extracellular signal-regulated kinase in the cancer endothelium [52]. Under certain experimental conditions, heparin may also induce apoptosis and differentiation of neoplastic cells. Additionally, heparin regulates the expression of certain oncogenes, including c-myc and c-fos [53].

\section{Targeted antineoplastic effect of LMWH?}

The specific mechanism of the antineoplastic effect of LMWH has not yet been clearly determined. Further laboratory and clinical trials are required in order to determine whether there is one mechanism responsible for this antitumor impact for all cancer types, or if some mechanisms are special for selected tumors. Surely, some processes are universal for the majority of malignancies, for instance the role of chemokines in metastasis formation [26]. Therefore, it seems that the effect of $\mathrm{LMWH}$ on them could also be present in all malignancies.

\section{LMWH as cancer progression stimulants}

Apart from the described theories of the antineoplastic effect of $L M W H$, there is still some risk of cancer promotion by anticoagulants. It could happen by immunomodulation [46] or by promotion of angiogenesis [44], as described above. Further research is still required.

\section{In vitro and in vivo studies}

The antineoplastic properties of LMWH were confirmed in in vivo trials on animals. The effect of tinzaparin on lung metastases of melanoma B16 was studied in a mouse model. A single, subcutaneous drug dose before the cancer cell inoculation reduced metastatic tumor formation by $89 \%$ in comparison to the control. Repeated tinzaparin administration once a day for 14 days before the cancer cell infusion caused a $96 \%$ reduction of the frequency of lung tumors. No severe adverse effects were observed [54].

In order to assess the influence of LMWH on the glycocalyx, enoxaparin was administered intravenously to mice deprived of syndecan-1, the lack of which disturbs the structure of the glycocalyx, and to the wild type after cancer cell inoculation. Almost complete elimination of metastatic tumors was observed in the wild type, and a lower reduction in the knock-out mice [30].

As heparin administration may cause bleeding, its derivates characterized by no anticoagulatory properties were generated. Such substances $-N$-acetylheparin, reduced oxyheparin and $\mathrm{N}$-acetyl-reduced oxyheparin - possess antiheparinase and anti-metastatic properties, although lower than heparin $[55,56]$. This suggests that heparins with no anticoagulatory properties could become new anti-tumor drugs, individually or in combination with standard chemotherapy and without the risk of bleeding.

For reasons of expediency, orally active heparin derivatives may prove beneficial in oncological treatment. The antineoplastic effect of conjugates of heparin with liposomes as well as heparins covered with proabsorbant substances were studies in vitro and in vivo [57]. In an in vivo study in mouse, liposomic heparins were administered 20 minutes before and for 14 days after B16F10 melanoma cell inoculation. The liposomic heparins dose-dependently reduced the number of lung metastases 2 - and 5-fold, when administered both intravenously and orally. This suggests that orally administered heparins may become standard in oncological treatment [57]. 
Table 2. Descriptions and results of available clinical trials concerning the antineoplastic effects of LMWH

\begin{tabular}{|c|c|c|c|c|c|}
\hline Heparin & Type of cancer & $\begin{array}{l}\text { Patients' } \\
\text { characteris- } \\
\text { tics; } n\end{array}$ & Comment & Effect & Reference \\
\hline $\begin{array}{l}\text { nadroparin/ } \\
\text { placebo for } \\
6 \text { weeks }\end{array}$ & $\begin{array}{l}\text { metastasized } \\
\text { or locally } \\
\text { advanced solid } \\
\text { tumors }\end{array}$ & 302 & $\begin{array}{l}\text { Malignancy and Low Molec- } \\
\text { ular Weight-Heparin Thera- } \\
\text { py (MALT) }\end{array}$ & $\begin{array}{l}\text { In the intention-to-treat analysis the overall hazard } \\
\text { ratio of mortality was } 0.75(95 \% \mathrm{Cl}: 0.59-0.96) \\
\text { with a median survival } 8.0 \text { months in the } \\
\text { nadroparin groups vs. } 6.6 \text { in placebo }\end{array}$ & {$[59]$} \\
\hline $\begin{array}{l}\text { dalteparin/ } \\
\text { placebo for } \\
1 \text { year }\end{array}$ & $\begin{array}{l}\text { advanced solid } \\
\text { tumors }\end{array}$ & 385 & $\begin{array}{l}\text { The Fragmin Advanced } \\
\text { Malignancy Outcome Study } \\
\text { (FAMOUS) }\end{array}$ & $\begin{array}{l}\text { The Kaplan-Meier survival estimated at } 1,2 \text {, and } \\
3 \text { years after randomization was similar ( } 46 \%, 27 \% \text {, } \\
\text { and } 21 \% \text { vs. } 41 \%, 18 \% \text {, and } 12 \%, p=0.19) \text {; in a sub- } \\
\text { group (dalteparin, } n=55 \text {; and placebo, } n=47) \\
\text { alive } 17 \text { months after randomization - Kaplan- } \\
\text { Meier survival estimated at } 2 \text { and } 3 \text { years from ran- } \\
\text { domization ( } 78 \% \text { vs. } 55 \% \text { and } 60 \% \text { vs. } 36 \% \text {, respec- } \\
\text { tively, } p=0.03 \text { ) }\end{array}$ & {$[62]$} \\
\hline $\begin{array}{l}\text { dalteparin/ } \\
\text { coumarin } \\
\text { derivative for } \\
6 \text { months }\end{array}$ & $\begin{array}{l}\text { olid tumors } \\
\text { and VTE }\end{array}$ & 602 & Connected to CLOT & $\begin{array}{l}\text { In patients with non-metastatic cancer, a } 20 \% \\
\text { mortality rate in the dalteparin group compared } \\
\text { with } 36 \% \text { with warfarin (HR } 0.50 ; 95 \% \mathrm{Cl}: 0.27- \\
0.95 ; p=0.03 \text { ). No benefit in patients with } \\
\text { metastatic cancer ( } 72 \% \text { vs. } 69 \% \text {, respectively; } \\
\text { HR } 1.1 ; 95 \% \mathrm{Cl}: 0.87-1.4 ; p=0.46) \text {. }\end{array}$ & {$[60]$} \\
\hline $\begin{array}{l}\text { dalteparin for } \\
5-7 \text { days and } \\
\text { a coumarin } \\
\text { derivative for } \\
6 \text { months/dal- } \\
\text { teparin alone } \\
\text { for } 6 \text { months }\end{array}$ & $\begin{array}{l}\text { solid tumors } \\
\text { and VTE }\end{array}$ & 676 & $\begin{array}{l}\text { Randomized Comparison of } \\
\text { Low-Molecular-Weight He- } \\
\text { parin versus Oral Anticoagu- } \\
\text { lant Therapy for the Preven- } \\
\text { tion of Recurrent Venous } \\
\text { Thromboembolism in } \\
\text { Patients with Cancer (CLOT) }\end{array}$ & $\begin{array}{l}\text { The respective mortality rates at six months } \\
\text { were } 39 \% \text { in the dalteparin alone group and } 41 \% \\
(p=0.53) \text { in the dalteparin/coumarin group }\end{array}$ & {$[64]$} \\
\hline $\begin{array}{l}\text { dalteparin with } \\
\text { chemotherapy } \\
\text { (cyclophos- } \\
\text { phamide, } \\
\text { epirubicin and } \\
\text { vincristine - } \\
\text { CEV) or } \\
\text { chemotherapy } \\
\text { (CEV) alone }\end{array}$ & $\begin{array}{l}\text { small cell lung } \\
\text { carcinoma }\end{array}$ & 84 & $\begin{array}{l}\text { The long-term good results } \\
\text { of this trial led the authors } \\
\text { to begin a new study to test } \\
\text { the efficacy of extending the } \\
\text { duration of LMWH adminis- } \\
\text { tration for up to } 1 \text { year. In } \\
\text { this study, combination CT } \\
\text { will include cisplatin in limit- } \\
\text { ed and extensive stage } \\
\text { patients and early combina- } \\
\text { tion chemo-radiotherapy } \\
\text { in limited stage patients. }\end{array}$ & $\begin{array}{l}\text { Overall tumor response rates higher in the group } \\
\text { receiving dalteparin. Median progression-free sur- } \\
\text { vival, median overall survival higher in the group } \\
\text { receiving dalteparin. Similar improvement in sur- } \\
\text { vival with LMWH treatment occurred in patients } \\
\text { with both limited and extensive disease stages. } \\
\text { The risk of death in the experimental group lower } \\
\text { than in the control group }\end{array}$ & {$[63]$} \\
\hline $\begin{array}{l}\text { dalteparin with } \\
\text { standard treat- } \\
\text { ment vs. stan- } \\
\text { dard treatment } \\
\text { alone for } \\
24 \text { weeks }\end{array}$ & $\begin{array}{l}\text { small or non- } \\
\text { small cell lung } \\
\text { cancer }\end{array}$ & $\begin{array}{c}2200 \\
\text { (planned) }\end{array}$ & $\begin{array}{l}\text { Fragmin }{ }^{\circledR} \text { added to stan- } \\
\text { dard therapy in patients } \\
\text { with lung cancer } \\
\text { (FRAGMATIC) }\end{array}$ & $\begin{array}{l}\text { Estimated Primary Completion Date: August } 2012 . \\
\text { Primary outcome: overall survival. } \\
\text { Secondary outcome measures: venous thrombotic } \\
\text { event free survival, serious adverse events, metas- } \\
\text { tasis-free survival, toxicity, quality of life, levels of } \\
\text { breathlessness, anxiety and depression, cost effec- } \\
\text { tiveness and cost utility. } \\
\text { It will be one of the biggest lung cancer trials ever } \\
\text { conducted in the world }\end{array}$ & {$[53]$} \\
\hline $\begin{array}{l}\text { tinzaparin for } \\
12 \text { weeks plus } \\
\text { standard treat- } \\
\text { ment in the } \\
\text { local centre vs. } \\
\text { standard treat- } \\
\text { ment in the } \\
\text { local centre }\end{array}$ & $\begin{array}{l}\text { non-small cell } \\
\text { lung cancer }\end{array}$ & $\begin{array}{c}800 \\
\text { (planned) }\end{array}$ & $\begin{array}{l}\text { Effect of Low Molecular } \\
\text { Weight Heparin: Tinzaparin } \\
\text { in Lung Tumours (TILT) }\end{array}$ & $\begin{array}{l}\text { Estimated Study Completion Date: August } 2015 \\
\text { Primary outcome: overall 3-year mortality } \\
\text { Secondary outcome: major bleeding time, sympto- } \\
\text { matic VTE events, cancer-related mortality, dis- } \\
\text { ease-free survival }\end{array}$ & {$[61]$} \\
\hline $\begin{array}{l}\text { dalteparin with } \\
\text { standard care } \\
\text { vs. placebo } \\
\text { with standard } \\
\text { care for } 2 \text { years }\end{array}$ & $\begin{array}{l}\text { mixed solid } \\
\text { tumors } \\
\text { (advanced } \\
\text { stages) }\end{array}$ & 138 & $\begin{array}{l}\text { The study became open } \\
\text { labeled, with patients } \\
\text { receiving either LMWH } \\
\text { injections plus standard } \\
\text { clinical care or standard } \\
\text { clinical care alone. }\end{array}$ & $\begin{array}{l}\text { No survival benefit demonstrated for LMWH in } \\
\text { patients with advanced cancer }\end{array}$ & {$[65]$} \\
\hline
\end{tabular}




\section{Clinical trials}

Clinical trials concerning the problem described may be divided into two main groups. The first concerns patients with cancer selected from the group with established VTE treated with anticoagulants. The primary outcome is the pharmacokinetics of anticoagulants and the overall survival is the secondary one. The second branch of studies includes trials on patients with cancer without established VTE.

ASCO carried out a metaanalysis and systemic review of randomized clinical trials concerning the effectiveness and safety of trials with anticoagulants on patients with cancer without VTE. In 11 studies, a significant decrease in 1-year overall mortality was observed. The relative risk (RR) was 0.905 (95\% Cl: 0.847-0.967; P 5.003) for all anticoagulants and 0.877 (95\% Cl: 0.789-0.975; P 5.015) for LMWH [58]. Descriptions and results of the trials available are shown in Table 2.

The studies described, however promising they seem, are limited due to the number of patients analyzed, their heterogeneity, diversity of prognostic factors, outdated protocol of chemotherapy and limited data on the frequency of adverse effects. There are expectations for the results of the FRAGMATIC trial (Fragmin ${ }^{\circledR}$ added to standard therapy in patients with lung cancer) [53]. It is a randomized, multicentre phase III trial assessing the effect of dalteparin added to standard treatment for 24 weeks for patients with small or nonsmall cell lung cancer. The primary completion date for 2200 patients should be August 2012. FRAGMATIC's results may prove crucial in creating new recommendations for preventive administration of LMWH in oncological treatment.

The MALT (Malignancy and Low Molecular Weight Heparin Therapy) study included patients with advanced solid tumors of different types who were randomly assigned to the group receiving nadroparin or placebo for 6 weeks. After a year an overall survival benefit was observed among the nadroparin group. It was the first randomized, placebo-controlled study to observe a survival benefit of LMWH in the study population as a whole [59].

Another randomized clinical trial was carried among cancer patients treated with dalteparin for deep venous thrombosis either for 6 months or initially only. Mortality was decreased in the dalteparin group among patients with limited disease, but not in the group with metastases [60].

The results of trials designed for patients with cancer without VTE are also promising. A randomized clinical trial included patients with small cell lung cancer, treated with either chemotherapy alone, or with LMWH. The mean progressionfree survival was significantly longer for the group with additional administration of LMWH. A survival benefit was observed both for patients with limited and those with metastatic disease [63].

The available studies do not permit analyses of the influence on cancer type [58]. It was suggested that the beneficial effect of LMWH on mortality is more likely for patients with early-stage cancer or with a more favorable prognosis than those with advanced disease [60].

\section{Summary}

There is strong evidence that the coagulation cascade plays an important role in cancer metastasis and angiogenesis. The anti-tumor effect of heparins, particularly LMWH, has been confirmed. These anticoagulants inhibit cancer cell growth and metastasis formation in several ways.

Differences between the antineoplastic properties of LMWH heparins were described. In the studies analyzed, tinzaparin was often used as a representative of heparins. This may be related to its better vascular distribution and longer half-life than other LMWH [66-69].

Despite positive results of the in vitro, in vivo and clinical studies, international societies of clinical oncology do not currently recommend LMWH administration for improving survival. Large clinical trials are still necessary.

\section{References}

1. Salzman EW, Rosenberg RD, Smith MH, Lindon JN, Favreau L. Effect of heparin and heparin fractions on platelet aggregation. J Clin Invest 1980; 65: 64-73.

2. Hirsh J, Warkentin TE, Shaughnessy SG et al. Heparin and low-molecular-weight heparin: mechanisms of action, pharmacokinetics, dosing, monitoring, efficacy, and safety. Chest 2001;119 (1 Suppl): 64S-94S.

3. Andersson LO, Barrowcliffe TW, Holmer E, Johnson EA, Söderström G. Molecular weight dependency of the heparin potentiated inhibition of thrombin and activated factor X. Effect of heparin neutralization in plasma. Thromb Res 1979; 15: 531-41.

4. Kelton JG, Hirsh J. Bleeding associated with antithrombotic therapy. Semin Hematol 1980; 17: 259-1.

5. Blajchman MA, Young E, Ofosu FA. Effects of unfractionated heparin, dermatan sulfate and low molecular weight heparin on vessel wall permeability in rabbits. Ann NY Acad Sci 1989; 556: 245-54.

6. Clowes AW, Karnovsky MJ. Suppression by heparin of smooth muscle cell proliferation in injured arteries. Nature 1977; 265: 625-6.

7. Shaughnessy SG, Young E, Deschamps P, Hirsh J. The effects of low molecular weight and standard heparin on calcium loss from the fetal rat calvaria. Blood 1995; 86: 1368-73.

8. Gordon SG. Cancer procoagulant. Eth Enzymol 1994; 244: 568-83.

9. Rajan R, Levine M, Gent M, Hirsh J, Geerts W, Skingley P, Julian J. The occurrence of subsequent malignancy in patients presenting with deep vein thrombosis: results from a historical cohort study. Thromb Haemost 1998; 79: 19-22.

10. Heit JA, Silverstein MD, Mohr DN, Petterson TM, O'Fallon WM, Melton LJ 3rd. Risk factors for deep vein thrombosis and pulmonary embolism: a population-based case-control study. Arch Intern Med 2000; 160: 809-15.

11. Luzzatto G, Schafer Al. The prethrombotic state in cancer. Semin Oncol 1990; 17: 147-59.

12. Lee AY, Levine MN. Venous thromboembolism and cancer: risks and outcomes. Circulation 2003; 107 (23 Suppl 1): 117-21.

13. Tafur AJ, Kalsi H, Wysokinski WE et al. The association of active cancer with venous thromboembolism location: a population-based study. Mayo Clin Proc 2011; 86: 25-30.

14. Lyman GH, Khorana AA, Falanga A, et al. American Society of Clinical Oncology guideline: recommendations for venous thromboembolism prophylaxis and treatment in patients with cancer. J Clin Oncol 2007; 25: 5490-505.

15. Mandal M, Falanga A, Roila F. ESMO Guidelines Working Group. Management of venous thromboembolism in cancer patients: ESMO Clinical Recommendations. Ann Oncol 2009; 20:182-4.

16. NCCN Clinical Practice Guidelines in Oncology. Venous Thromboembolic Disease. Version 2.2011. NCCN.org

17. Steeg PS. Tumor metastasis: mechanistic insights and clinical challenges. Nat Med 2006; 12: 895-904.

18. Kuderer NM, Ortel TL, Francis CW. Impact of venous thromboembolism and anticoagulation on cancer and cancer survival. J Clin Oncol 2009; 27: 4902-11.

19. Jiang X, Guo YL, Bromberg ME. Formation of tissue factor-factor VIlafactor Xa complex prevents apoptosis in human breast cancer cells. Thromb Haemost 2006; 96: 196-201. 
20. Versteeg HH, Spek CA, Slofstra SH Diks SH, Richel DJ, Peppelen bosch MP. FVIIa: TF induces cell survival via G12/G13- dependent Jak/STAT activation and BcIXL production. Circ Res 2004; 94: 1032-40.

21. Mousa SA, Mohamed S. Inhibition of endothelial cell tube formation by the low molecular weight heparin, tinzaparin, is mediated by tissue factor pathway inhibitor. Thromb Haemost 2004; 92: 627-33.

22. Amirkhosravi A, Meyer T, Amaya M, Davila M, Mousa SA, Robson T, Francis JL. The role of tissue factor pathway inhibitor in tumor growth and metastasis. Semin Thromb Hemost 2007; 33: 643-52.

23. Sierko E, Wojtukiewicz MZ, Kisiel W. The role of tissue factor path way inhibitor- 2 in cancer biology. Semin Thromb Hemost 2007; 33: 653-9.

24. Mousa SA. Are low molecular weight heparins the same? Methods Mol Med 2004; 93: 49-59.

25. Mousa SA. The low molecular weight heparin, tinzaparin, in throm bosis and beyond. Cardiovasc Drug Rev 2002; 20: 199-216.

26. Mellor P, Harvey JR, Murphy KJ Pye D, O'Boyle G, Lennard TW, Kirby JA, Ali S. Modulatory effects of heparin and short-length oligosaccharides of heparin on the metastasis and growth of LMD MDA-MB 231 breast cancer cells in vivo. Br J Cancer 2007; 97: 761-8.

27. Harvey JR, Mellor P, Eldaly H Lennard TW, Kirby JA, Ali S. Inhibition of CXCR4-mediated breast cancer metastasis: a potential role for heparinoids? Clin Cancer Res 2007; 13: 1562-70.

28. Mulivor AW, Lipowsky HH. Role of glycocalyx in leukocyte-endothelial cell adhesion. Am J Physiol Heart Circ Physiol 2002; 283: H1282-91.

29. Kainulainen V, Nelimarkka L, Järveläinen H Laato M, Jalkanen M, Elenius K. Suppression of Syndecan-1 expression in endothelial cells by tumor necrosis factor-a. J Biol Chem 2006; 271: 18759-66.

30. Van Sluis GL, Nieuwdorp M, Kamphuisen PW, van der Vlag J, Van Noorden CJ, Spek CA. A low molecular weight heparin inhibits experimental metastasis in mice independently of the endothelial glycocalyx. PLoS One 2010; 5: e11200.

31. Fritzsche J, Simonis D, Bendas G. Melanoma cell adhesion can be blocked by heparin in vitro: suggestion of VLA-4 as a novel target for antimetastatic approaches. Thromb Haemost 2008; 100: 1166-75.

32. Borsig L. Antimetastatic activities of heparins and modified heparins Experimental evidence. Thromb Res 2010; 125 Suppl 2: S66-71.

33. Kansas GS. Selectins and their ligands: current concepts and controversies. Blood 1996; 88: 3259-87.

34. Borsig L, Wong R, Hynes RO, Varki NM, Varki A. Synergistic effects of $\mathrm{L}$ - and $\mathrm{P}$-selectin in facilitating tumor metastasis can involve nonmucin ligands and implicate leukocytes as enhancers of metastasis. Proc Natl Acad Sci U S A 2002; 99: 2193-8.

35. Nelson RM, Cecconi O, Roberts WG, Aruffo A, Linhardt RJ, Bevilac qua MP. Heparin oligosaccharides bind L- and P-selectin and inhib it acute inflammation. Blood 1993; 82: 3253-8.

36. Koenig A, Norgard-Sumnicht K, Linhardt R, Varki A. Differential interactions of heparin and heparan sulfate glycosaminoglycans with the selectins. Implications for the use of unfractionated and low molecular weight heparins as therapeutic agents. J Clin Invest 1998; 101: 877-89.

37. Borsig L Antimetastatic activities of modified heparins: selectin inhibition by heparin attenuates metastasis. Semin Thromb Hemost 2007 33: 540-6.

38. Ludwig RJ, Boehme B, Podda M, et al. Endothelial P-selectin as a target of heparin action in experimental melanoma lung metastasis. Cancer Res 2004; 64: 2743-50.

39. Borsig L, Wong R, Feramisco J, Nadeau DR, Varki NM, Varki A. Heparin and cancer revisited: mechanistic connections involving platelets, P-selectin, carcinoma mucins, and tumor metastasis. Proc Natl Acad Sci U S A 2001; 98: 3352-7.

40. Stevenson JL, Varki A, Borsig L. Heparin attenuates metastasis mainly due to inhibition of P- and L-selectin, but non-anticoagulant heparins can have additional effects. Thromb Res 2007; 120 Suppl 2: S107-11.

41. Stevenson JL, Choi SH, Varki A. Differential metastasis inhibition by clinically relevant levels of heparins - correlation with selectin inhibition, not antithrombotic activity. Clin Cancer Res 2005; 11 (19 Pt 1): 7003-11.

42. Mousa S. Anticoagulants in thrombosis and cancer: the missing link. Semin Thromb Hemost 2002; 28: 45-52.
43. Collen A, Smorenburg SM, Peters E, Lupu F, Koolwijk P, Van Noorden C, van Hinsbergh VW. Unfractionated and low molecular weight heparin affect fibrin structure and angiogenesis in vitro. Cancer Res 2000; 60: 6196-200.

44. Norrby K, Nordenhem A. Dalteparin, a low-molecular-weight heparin, promotes angiogenesis mediated by heparin-binding VEGF-A in vivo. APMIS 2010;118: 949-57.

45. Sylvester DM, Liu SY, Meadows GG. Augmentation of antimetastatic activity of interferon and tumor necrosis factor by heparin. Immunopharmacol Immunotoxicol 1990; 12: 161-80.

46. Smorenburg SM, Van Noorden CJ. The complex effects of heparins on cancer progression and metastasis in experimental studies. Pharmacol Rev 2001; 53: 93-105

47. Takahashi H, Ebihara S, Okazaki T, Asada M, Sasaki H, Yamaya M. A comparison of the effects of unfractionated heparin, dalteparin and danaparoid on vascular endothelial growth factor-induced tumour angiogenesis and heparanase activity. Br J Pharmacol 2005; 146: 333-43.

48. Ilan N, Elkin M, Vlodavsky I. Regulation, function and clinical significance of heparanase in cancer metastasis and angiogenesis. Int J Biochem Cell Biol 2006; 38: 2018-39.

49. Goldshmidt O, Zcharia E, Abramovitch R, et al. Cell surface expression and secretion of heparanase markedly promote tumor angiogenesis and metastasis. PNAS U S A 2002; 99: 10031-6.

50. Irimura T, Nakajima M, Nicolson GL. Chemically modified heparins as inhibitors of heparan sulfate specific endo-beta-glucuronidase (heparanase) of metastatic melanoma cells. Biochemistry 1986; 25 : 5322-8.

51. Casu B, Vlodavsky I, Sanderson RD. Non-Anticoagulant Heparins and Inhibition of Cancer. Pathophysiol Haemost Thromb 2007; 36: 195-203.

52. Alifano M, Benedetti G, Trisolini R. Can low-molecular-weight heparin improve the outcome of patients with operable non-small cell lung cancer? An urgent call for research. Chest 2004; 126: 601-7.

53. Griffiths GO, Burns S, Noble SI, Macbeth FR, Cohen D, Maughan TS. FRAGMATIC: a randomised phase III clinical trial investigating the effect of fragmin added to standard therapy in patients with lung cancer. BMC Cancer 2009; 9: 355.

54. Amirkhosravi A, Mousa SA, Amaya M, Francis JL Antimetastatic effect of tinzaparin, a low-molecular-weight heparin. J Thromb Haemost 2003; 1: 1972-6.

55. Nakajiama M, Irimura T, Di Ferrante N, Nicolson GL. Metastatic melanoma cell heparanase. Characterization of heparan sulfate degradation fragments produced by B16 melanoma endoglucuronidase. J Biol Chem 1984; 259: 2283-90.

56. Naggi A, Casu B, Perez M, et al. Modulation of the heparanase-inhibiting activity of heparin through selective desulfation, graded Nacetylation, and glycol splitting. J Biol Chem 2005; 280: 12103-13.

57. Lee DY, Park K, Kim SK, Park RW, Kwon IC, Kim SY, Byun Y. Antimetastatic effect of an orally active heparin derivative on experimentally induced metastasis. Clin Cancer Res 2008; 14: 2841-9.

58. Kuderer NM, Khorana AA, Lyman GH, Francis CW. A meta-analysis and systematic review of the efficacy and safety of anticoagulants as cancer treatment: impact on survival and bleeding complications. Cancer 2007; 110: 1149-61.

59. Klerk CP, Smorenburg SM, Otten HM et al. The effect of low molecular weight heparin on survival in patients with advanced malignancy. J Clin Oncol 2005; 23: 2130-5.

60. Lee AY, Rickles FR, Julian JA et al. Randomized comparison of lowmolecular-weight heparin and coumarin derivatives on the survival of patients with cancer and venous thromboembolism. J Clin Oncol 2005; 23: 2123-9.

61. [ClinicalTrials.gov] NCT00475098.

62. Kakkar AK, Levine MN, Kadziola Z, et al. Low molecular weight heparin, therapy with dalteparin, and survival in advanced cancer: The fragmin advanced malignancy outcome study (FAMOUS). J Clin Oncol 2004; 22: 1944-8.

63. Altinbas M, Coskun HS, Er O, Ozkan M, Eser B, Unal A, Cetin M, Soyuer $\mathrm{S}$. A randomized clinical trial of combination chemotherapy with and without low-molecular-weight heparin in small cell lung cancer. J Thromb Haemost 2004; 2: 1266-71. 
64. Lee AY, Levine MN, Baker RI, et al.; Randomized Comparison of LowMolecular-Weight Heparin versus Oral Anticoagulant Therapy for the Prevention of Recurrent Venous Thromboembolism in Patients with Cancer (CLOT) Investigators. Low molecular-weight heparin versus a coumarin for the prevention of recurrent venous thromboembolism in patients with cancer. N Engl J Med 2003; 349: 146-53.

65. Sideras K, Schaefer PL, Okuno SH, et al. Low-molecularweight heparin in patients with advanced cancer: a phase 3 clinical trial. Mayo Clin Proc 2006; 81: 758-67.

66. Mahé I, Aghassarian M, Drouet L, Bal Dit-Sollier C, Lacut K, Heilmann JJ, Mottier D, Bergmann JF. Tinzaparin and enoxaparin given at prophylactic dose for eight days in medical elderly patients with impaired renal function: a comparative pharmacokinetic study. Thromb Haemost 2007; 97: 581-6.

67. Mahe I, Gouin-Thibault I, Drouet L, Simoneau G, Di Castillo H, Siguret V, Bergmann JF, Pautas E. Elderly medical patients treated with prophylactic dosages of enoxaparin: influence of renal function on anti-Xa activity level. Drugs Aging 2007; 24: 63-71.

68. Pautas E, Gouin I, Bellot O, Andreux JP, Siguret V. Safety profile of tinzaparin administered once daily at a standard curative dose in two hundred very elderly patients. Drug Saf 2002; 25: 725-33.

69. Siguret V, Pautas E, Février M et al. Elderly patients treated with tinzaparin (Innohep) administered once daily (175 anti-Xa IU/kg): antiXa and anti-Ila activities over 10 days. Thromb Haemost 2000; 84 800-4.

\section{Address for correspondence}

\section{Justyna Bochenek}

Department of Clinical Oncology

Krakow University Hospital

Sniadeckich 10

31-531 Krakow, Poland

e-mail: bochenekjm@gmail.com

Submitted: $\quad 26.03 .2012$

Accepted: $\quad$ 7.05.2012 